\title{
The Issue of Transfer Pricing Nowdays in Era of Globalization
}

\author{
Santi Yopie*, Oka Budiman** \\ DOI: 10.29322/IJSRP.11.07.2021.p11568 \\ http://dx.doi.org/10.29322/IJSRP.11.07.2021.p11568
}

\begin{abstract}
This research objective is to examines the development of transfer pricing issue in Indonesia and to be a guide for further research in transfer pricing issue. This research is used qualitative method which reviewed 15 previous scientific research paper in the span of 2004-2020. In the era of globalization encourages entreprenuers to open up a business opportunities in various countries. The different of tax policies may give advantage to practice transfer pricing issue. So, the transfer pricing knowledge is become a challenging of every entreprenuers which need to study more deeply about the principle of fairness of arm's length principle. The result of this research is showed the application of advance pricing agreement (APA) is a pretty good thing for tax authorities to pay attention for. It is hoped that APA will be a solution in solving the problem of abuse practice of transfer pricing. It can increase the potential for state revenue and minimize the abuse practice of transfer pricing in Indonsia. Further research can be recommended to conduct research on the application of APA because this is still new in Indonesia.
\end{abstract}

Index Terms- Tranfer pricing, Advance Pricing Agreement, APA, Arm's length, Tax

\section{INTRODUCTION}

The development of information and communication technology is growing rapidly, it is very encouraging for entrepreneurs to develop trade globalization and open up business opportunities in various countries. The development of the global market has encouraged many companies to expand their business overseas. Competitive costs and access to resources, customer access, technological advances, infrastructure progress and different tax rate policies between countries are alternative considerations for entrepreneurs to develop their businesses in various countries. The development of multinational companies will increase the growth of economic integration between countries (Hansen \& Rugraff, 2011).

Entrepreneurs consider various aspects in the form of cost and access to competitive resources, customer access, technological advances, infrastructure progress and tax rate policies in carrying out some of their business activities, then some of their business activities are distributed to several different geographical locations (Arham, Firmansyah \& Nor, 2020 ). This gives rise to transactions between companies that have relationships (affiliates). Bernard, Jensen and Schott (2006) argue that any transactions related to company affiliation would be contrary to the arm's length principles. This is because there is a possibility that transactions are intentionally made to increase profits and are reported in other countries that have lower tax rates (tax haven countries), while costs are allocated in countries with high tax rates.

In principle, every company wants to get as much income as possible with the burden of suppressing the smallest burden. By expanding the scope of marketing and sales overseas, one of the challenges that every company considers is income tax. Each country has a different income tax policy so that in order to maximize profits, companies need to carry out careful tax planning in accordance with the laws and regulations in force in each country. The implementation of tax policies in each country is different so that with the increasing number of multinational companies, the international tax world is faced with a phenomenon that has basically existed for a long time but needs special attention at this time, namely supervising multinational companies so as not to violate or violate tax regulations. applicable in every country. Several companies have taken advantage of affiliated transactions to carry out transfer pricing practices. With the development of trade globalization, the issue of transfer pricing has become the focus of attention, especially on tax revenues for the state. Appeals against transfer pricing provisions in US federal courts increased by 40\%, from US\$ 3.4 billion to US\$ 4.8 billion (Borkowski, 2000). There are more than $60 \%$ of multinational companies that carry out transfer pricing, this is an important issue (OECD, 2017). However, there was an increase in disputes over transfer pricing cases by $20 \%$ in 2018 when compared to 2017 . This increase was higher when compared to other disputes which only increased by $10 \%$.

Global Financial Integrity (2012) released that developing countries in the period 2001-2010 lost their state revenues of US\$ 5.86 trillion or around US\$ 586 billion. During the same year, there was an illegal flow of US\$ 123 billion or an average of US\$12.3 billion per year out of Indonesia. Seeing the amount of illegal money in circulation and the loss of state revenue due to this transfer pricing case, the issue of transfer pricing becomes an interesting topic to be discussed from time to time. The Tax Justice Network (2010) said that 60-70\% of multinational companies practice transfer pricing. While $80 \%$ of developing country's income comes from tax revenue. Therefore, the tax potential on the issue of transfer pricing is very large. The tax authorities will continue to "pursue" potential taxes that can be collected 
through tax audits to multinational companies in order to meet state revenue targets.

Seeing the frequent occurrence of disputes and disputes between countries due to differences in transfer pricing provisions, the OECD develops solutions in the event of a dispute. The first solution is the Mutual Agreement Procedure (MAP) which is defined as an administrative procedure contained in the Double Taxation Avoidance Agreement (P3B) with the aim of resolving problems between countries. However, this problem is not easily solved using the MAP method, due to the strict transfer pricing provisions applied in each country. Therefore, the OECD developed another settlement scheme called the Advance Pricing Agreement (APA), where the tax authorities of a country make an agreement.

\section{IDENTIFY, RESEARCH AND COLLECT IDEA}

There is a large literature on accounting, management science, and economics containing many models that address the issue of resource allocation and transfer pricing (Watson \& Baumler, 1975). Some of the earliest statements on the issue of transfer pricing were examined by Hirshleifer (1956), Dean (1955), and Cook (1955). Transfer pricing is the price charged by a division for a product to other divisions in a multinational company, transfer pricing is usually used to minimize income taxes and import taxes (Horngren, 2008). Transfer pricing systems generally provide prices for commodities that are produced and consumed internally. The internal pricing mechanism depends on transfer costs over material costs for finished products and profits which are used to evaluate performance per division (Khalik \& Lusk, 1974).

Abdallah (1989) states that the decision to transfer pricing for multinational companies is important, complex, flexible and complicated because it affects important parts of a company such as marketing, production, location, transportation and finance. Transfer pricing is something that is done by many multinational companies. As mentioned by Eccles (1985) and Spicer (1988), transfer pricing is a strategy, not a procedure.

Transfer pricing in a multinational company is undeniably an important international tax issue, which makes national companies and tax authorities unable to dispute in tax courts due to the increasing number of transfer pricing cases (Mehafdi, 2000). The issue of transfer pricing is now the main discussion in the case of international tax disputes because it is believed that the potential for tax revenues of billions of dollars is lost due to loopholes in transfer pricing regulations through incorrect accounting records.

According to Martinson and McKee (2001), many countries have made changes to provisions related to transfer pricing to become more stringent, for example Australia which has increased tax officers related to transfer pricing cases and stated that any multinational company that does not follow these rules and provides false information can be prosecuted. The Australian Government focuses on several industries. Another example is Brazil which has its own transfer pricing provisions which do not follow the rules of the OECD, but every multinational company doing business with Brazil must pay attention to the terms and conditions of its country.

In the Regulation of the Director General of Taxes No. 32 of 2011 it is stated that there are 4 steps to apply the principle of fairness and business commons, namely conducting a comparability analysis and determining comparisons, determining the appropriate transfer pricing method, applying the principle of business prevalence and fairness based on a comparison analysis and determining transfer pricing in transactions with related parties. have a special relationship and document the steps in determining the fair price and fair profit in accordance with the provisions of the applicable laws and regulations. There are five ways to determine transfer pricing, namely the price comparison method between unrelated parties, the resale price method, the cost-plus method, the profit-sharing method and the transactional net income method.

Seeing the frequent occurrence of disputes and disputes between countries due to differences in transfer pricing provisions, the OECD develops solutions in the event of a dispute. The first solution is the Mutual Agreement Procedure (MAP) which is defined as an administrative procedure contained in the Double Taxation Avoidance Agreement (P3B) with the aim of resolving problems between countries. However, this problem is not easily solved using the MAP method, due to the strict transfer pricing provisions applied in each country. Therefore, the OECD has developed another settlement scheme called the Advance Pricing Agreement (APA), where the tax authority of a country makes an agreement with taxpayers and/or other country's tax authorities to determine the best criteria in determining transfer pricing with related parties. special for a certain period.

This study uses a qualitative method, this is by collecting articles and scientific research conducted in Indonesia and various countries in order to obtain a conceptual framework on how the application of transfer pricing is carried out and the problems that exist in the application of transfer pricing in various countries. This research contains 15 scientific articles in Indonesia in the span of $2004-2020$. 
Below are some studies that are relevant to current conditions and were carried out by several researchers in Indonesia:

\begin{tabular}{|c|c|c|c|c|}
\hline No. & Name & Method & Variable & Result \\
\hline 1 & $\begin{array}{l}\text { Oktaviana \& } \\
\text { Kristanto (2012) }\end{array}$ & Quantitative & $\begin{array}{l}\text { Dependent: effective tax } \\
\text { rate; Independent: Affliation } \\
\text { transaction }\end{array}$ & $\begin{array}{l}\text { Related transactions have a negative effect on the } \\
\text { effective tax rate }\end{array}$ \\
\hline 2 & Pradana (2014) & Quantitative & $\begin{array}{l}\text { Dependent: Transfer } \\
\text { pricing; Independent: Pajak, } \\
\text { Tunneling incentive, bonus } \\
\text { compensation }\end{array}$ & $\begin{array}{l}\text { Taxes have a significant effect on transfer pricing, and } \\
\text { tunneling incentives and bonus compensation have no } \\
\text { significant effect on transfer pricing transfer }\end{array}$ \\
\hline 3 & $\begin{array}{l}\text { Huda, } \\
\text { Nugraheni, } \\
\text { Kamarudin } \\
(2017)\end{array}$ & Normative & $\begin{array}{l}\text { International Taxation } \\
\text { Agreement, Mutual } \\
\text { Agreement Procedure, } \\
\text { Advance Pricing Agreement, } \\
\text { Tax Revenue on } \\
\text { International Taxation } \\
\text { Lawsuit }\end{array}$ & $\begin{array}{l}\text { The determination of transfer pricing is held by } \\
\text { multinational companies in order to minimize operating } \\
\text { performance and optimize tax arrangements as a top or } \\
\text { important priority. }\end{array}$ \\
\hline 4 & $\begin{array}{l}\text { Arham, } \\
\text { Firmansyah \& } \\
\text { Nor (2020) }\end{array}$ & Qualitative & $\begin{array}{l}\text { Dependent: Transfer pricing } \\
\text { agressiveness } \\
\text { Independetn: tax, tunneling } \\
\text { incentive, bonus mechanism }\end{array}$ & $\begin{array}{l}\text { The majority of test results on the effect of taxes and } \\
\text { tunneling incentives on transfer pricing aggressiveness } \\
\text { show a positive effect, while the majority of test results } \\
\text { on the effect of the bonus mechanism show no effect. }\end{array}$ \\
\hline 5 & Delloite (2020) & Normative & $\begin{array}{l}\text { Advance Pricing Agreement } \\
\text { (APA) }\end{array}$ & $\begin{array}{l}\text { Indonesia perfected the procedure for implementing the } \\
\text { transfer pricing agreement or Advance Pricing Agreement } \\
\text { (APA) by issuing the Minister of Finance Regulation } \\
\text { (PMK) Number 22/PMK.03/2020. }\end{array}$ \\
\hline
\end{tabular}

\section{DISCUSSION AND FINDINGS}

Indonesia's tax regulations have comprehensively regulated the practice of transfer pricing along with its implementations. However, the existing personnel within the tax authority are still has quality lack (Setiawan, 2013). This means that only a few tax auditors have a good knowledge of transfer pricing regulations. Therefore, when a taxpayer appeals the tax assessment issued by the tax authority, they often loses because they cannot defend their argument so that the amount of state revenue is reduced.

Setiawan (2013) also wrote that the database owned by tax authority is very limited. The number of personnel who can access this database is also limited, whereas in order to determine transfer pricing, the tax authority needs to fully understand about the economy, products, companies, profit levels, royalties, licenses, industry, and also the database of multinational companies who practice transfer pricing. Therefore, improving the quality of human resources within the tax authority environment who understand the practice of transfer pricing is crucial and important. The implementations of APA and MAP with taxpayers who conduct transactions with related parties and tax authorities of other countries is also believed to be able to maximize the potential state revenue from transfer pricing practices.

Aulia (2020) explains that from point of view of treaty law APA conducted by taxpayers and tax authorities or with other countries can be categorized as standard agreements, because most of the clauses in APA regulated in law. Therefore, the contents of APA cannot be changed by the parties involved, things that can be negotiated are the amount, time, price and other things that are part of the object of the agreement. Thus, if APA is implemented by stick to the principles of freedom of contract, consensual and good faith and in its implementation upholding the principle of win-win solution, then APA can be a solution for taxpayers and tax authorities to accommodate the needs of the parties involved, both guaranteeing state revenue in the taxation sector as well as protection of rights for taxpayers to avoid double taxations.

Jafri and Mustikasari (2018) wrote that the potential for transfer pricing practices by companies conducting transactions with related parties will increase if the country has a high tax rate and will shift its income to a country with a lower tax rate. The large control owned by the majority shareholder may result in transfer pricing practices by diverting profits and/or assets to a country with a lower tax rate without implementing arm's length principles for the benefit of the majority shareholder. This study shows that the abuse of transfer pricing is still very vulnerable to multinational companies that conducting transactions with related parties.

Rosad, Nugraha and Fahjri (2020), in their research show that one of the factors that influence the practice of transfer pricing is tax avoidance. Companies that conducting tax avoidance will tend to implement transfer pricing as a solution by diverting their profits and/or assets to countries with lower tax rates. While the other two research variables, which is exchange rate and leverage, do not affect the company's decision to implement transfer pricing.

Santoso (2004) explains, to minimize the abuse of transfer pricing practices, the APA solution can be applied. However, there are several things that are obstruct the implementation of APA in Indonesia, which is the lack of human resources within the tax authority 
environment who understand transfer pricing, documentation and data collection systems that have not been organized and adequate, the tax authorities must make continuous improvements in the form of making and/or revise the laws and regulations about transfer pricing. It is better for the tax authorities in Indonesia to study the implementation of APA that has been done by other countries and their implications for multinational companies and the business climate in Indonesia. Tax authorities also need to understand that APA implementation is voluntary, so tax authorities cannot force multinational companies to implement this. The challenge for tax authorities is how to make the implementation of this APA attractive to multinational companies.

Prananda and Triyanto (2020) explain that the company's tax burden affects the company's decision to implement transfer pricing. The bigger tax is paid, the greater potential for the company to implement transfer pricing. Multinational companies owned by foreigners also influence the company's decision to implement transfer pricing. This makes sense, because by having some of the shares of multinational companies in Indonesia owned by multinational companies abroad, it opens up the possibility of transfer pricing implementations within the company. Meanwhile, the bonus mechanism and the exchange rate which were also examined in this study were not proven to have an effect on the company's decision to implement transfer pricing.

Dewi and Mustikasari (2020) explained that the abuse of transfer pricing implementations causes national problems and becomes a global challenge because tax revenues and public awareness to pay taxes are still low. This is evidenced by the low tax ratio in Indonesia, compared to other Southeast Asian countries. The low tax ratio in Indonesia makes development management and growth in Indonesia not optimal. Transfer pricing implementations carried out in Indonesia occur due to several factors, such as the related parties between group companies, the implementation of the bonus system and mechanism and the company's desire to maximize profits by reducing the tax to a minimum, as well as foreign ownership. Therefore, the abuse of transfer pricing can be overcome by carrying out tax reforms and taking steps to manage and collect tax data.

Deloitte (2020) writes that Minister of Finance Regulation No. 22/PMK.03/2020 which expands the scope of APA is a good decision in order to minimize tax disputes in the field of transfer pricing. The implementation of Base Erosion and Profit Shifting (BEPS) and the application of country-by-country reports have increased tax audit activities in many countries. Therefore, it is hoped that the tax authorities in Indonesia can make clearer and more detailed guidelines related to the implementation of the APA which will help to eliminate uncertainty regarding this transfer pricing regulations. The strengthened and simplified APA framework certainly deserves evaluation when multinational companies design management strategies in Indonesia in relation to this transfer pricing implementations.

Related transaction have a negative effect on the effective tax rate (Oktaviana \& Kristanto, 2012). Transfer pricing will be influenced by tax rates and tunneling incentives (Pradana, 2014) however, the majority of test results on the effect of the bonus mechanism show no effect (Arham, Firmansyah \& Nor, 2020). Indonesia completed the procedure for implementing the transfer pricing agreement or Advance Pricing Agreement (APA) by issuing the Minister of Finance Regulation (PMK) Number 22/PMK.03/2020 (Delloite, 2020).

\section{CONCLUSION}

The implementation of transfer pricing in Indonesia still raises many questions about whether the implementation can be categorized as abuse of transfer pricing or not. Therefore, the implementation of the Advance Pricing Agreement (APA) is a good thing for the tax authorities to pay attention to. With the Minister of Finance Regulation No. 22/PMK.03/2020 which regulates the APA mechanism, makes legal certainty for multinational companies that want to implement APA clear. With this legal certainty, it is hoped that APA will become a solution in solving the problem of abuse of transfer pricing practices so as to increase the potential for state revenues and minimize abuse of transfer pricing practices in Indonesia. Further research can be recommended to conduct research on the application of APA because this is still new in Indonesia.

\section{REFERENCES}

Abdallah, Wagdy. 1989. International Transfer Pricing Policies, New York: Quorum Books.

Abdel-Khalik, A., \& Lusk, E. (1974). Transfer Pricing-A Synthesis. The Accounting Review, 49(1), 8-23. Retrieved April 25, 2021, from http://www.jstor.org/stable/244794

Arham, A., Firmansyah, A., \& Nor, A. (2020). Penelitian Transfer Pricing di Indonesia: Sebuah Studi Kepustakaan. Jurnal Online Insan Akuntan, 5(1), 57-72. doi:10.51211/joia.v5i1.1318

Astuti. 2008. Analisis Putusan Pengadilan Pajak Atas Sengketa Penentuan Harga Wajar Pada Transaksi Transfer Pricing.

Astuti. 2008. Analisis Putusan Pengadilan Pajak Atas Sengketa Penentuan Harga Wajar Pada Transaksi Transfer Pricing.

Borkowski, C.S. 2000. Transfer pricing advance pricing agreements: Current status by country. The International Tax Journal 26 (2), 116.

Bernard, A. B., Jensen, J. B., \& Schott, P. K. (2006). Transfer pricing by US - based multinational firms (No. w12493). National Bureau of Economic Research.

Dede Abdul Rosad, Erik Nugraha dan Rizki Fajri. 2020. Faktor-Faktor yang Mempengaruhi Keputusan Perusahaan untuk Melakukan Transfer Pricing. Bandung.

Dede Abdul Rosad, Erik Nugraha dan Rizki Fajri. 2020. Faktor-Faktor yang Mempengaruhi Keputusan Perusahaan untuk Melakukan Transfer Pricing. Bandung.

Deloitte. 2020. Indonesia Transfer Pricing Alert April 2020. Jakarta.

This publication is licensed under Creative Commons Attribution CC BY.

http://dx.doi.org/10.29322/IJSRP.11.07.2021.p11568

WwW.ijsrp.org 
Eccles, R. G. 1985. The Transfer Pricing Problem: A Theor3' for Practice. Lexington Books, Lexington, MA.

Hadi Setiawan. 2013. Transfer Pricing dan Risikonya Terhadap Penerimaan Negara.

Harris, D., R. Morck, J. Slemrod and B. Yeung. 1993. Income shifting in U.S. multinational companies, in: A. Giovannini, G. Hubbard and J. Slemrod, eds., Studies in international taxation (University of Chicago Press, Chicago, IL) 277-302.

Hasan Effendi Jafri dan Elia Mustikasari. 2018. Pengaruh Perencanaan Pajak, Tunneling Incentive dan Aset Tidak Berwujud Terhadap Perilaku Transfer Pricing pada Perusahaan Manufaktur yang Memiliki Hubungan Istimewa yang Terdaftar di Bursa Efek Indonesia Periode 2014-2016. Surabaya.

Hansen, M. W., \& Rugraff, E. (2011). Multinational corporations and local firms in emerging economies (p. 276). Amsterdam University Press.

Horngren, Datar dan Foster. 2008. Akuntansi Biaya, Penekanan Manajerial. Jilid 2 ed 12. Jakarta.

Huda, M. K., Nugraheni, N. \& Kamarudin, K. (2017). The Problem of Transfer Pricing in Indonesia. Internasional Journal of Economics and Finansial Issues (2017). 7(4), 139-143.

Iman Santoso. 2004. Advance Pricing Agreement dan Problematika Transfer Pricing dari Perspektif Perpajakan Indonesia. Surabaya.

Messaoud Mehafdi. 2000. The Ethics of International Transfer Pricing. Belanda.

Oktaviana, S. dan Kristanto, S. B. 2012. Transaksi Hubungan Istimewa dan Pengaruhnya Terhadap Tarif Pajak Efektif Perusahaan. Jurnal Kuntansi. Vol.12, No.2, November 2012: 701-716

Otto B. Martinson dan Tim C. McKee. 2001. Staying Out of Trouble with Transfer Pricing. Virginia.

Peraturan Direktur Jenderal Pajak No. 32 Tahun 2011 Tentang Penerapan Prinsip Kewajaran dan Kelaziman Usaha Dalam Transaksi Antara Wajib Pajak dengan Pihak yang Mempunyai Hubungan Istimewa.

Peraturan Menteri Keuangan No. 22/PMK.03/2020 Tentang Tata Cara Pelaksanaan Kesepakatan Harga Transfer (Advance Pricing Agreement)

Pradana, T. A. 2014. Pengaruh Pajak, Tunneling Incentive dan Kompensasi Bonus Terhadap

Keputusan Transfer Pricing Pada Perusahaan Industri Barang Konsumsi Yang Listing Di Bursa Efek Indonesia (BEI). Skripsi. Fakultas Ekonomi Universitas Pancasakti Tegal

Renita Rachma Dewi dan Elia Mustikasari. 2020. Analisis Penanganan Manipulasi Transfer Pricing Perpajakan Dalam Menjawab Tantangan Global. Denpasar.

Rihhadatul 'Aisy Prananda dan Dedik Nur Triyanto. 2020. Pengaruh Beban Pajak, Mekanisme Bonus, Exchange Rate dan Kepemilikan Asing Terhadap Indikasi Melakukan Transfer Pricing. Bandung.

Rosad, D. A., Nugraha, E., Fahjri, R. 2020. Faktor faktor yang mempengaruhi keputusan perusahaan untuk melakukan transfer pricing. Jurnal Akuntansi Netral, Akuntabel, Objektif. 2(2) Januari 2020.

Sesario Aulia. 2020. Advance Pricing Agreement Dalam Perspektif Hukum Perjanjian. Ponorogo.

Spicer, B. H. 1988. Towards an organizational theory of the transfer pricing process. Accounting Organizations and Society 13(3), 303324.

Sugeng, T. (2014), Putusan Mahkamah Agung Yang Menghukum Asian Agri Diapresiasi. Available from: http://www.m.liputan6.com/news/ read/2131393/putusan-ma-yangmenghukum-asian-agri-diapresiasi. [Last accessed on 2017 Feb 01]

Undang-Undang No. 36 Tahun 2008 Perubahan Keempat atas Undang-Undang No. 7 Tahun 1983 Tentang Pajak Penghasilan.

Watson D.J.H., Baumler J.V. (1975) Transfer pricing: a behavioural context. In: Emmanuel C., Otley D., Merchant K. (eds) Readings in Accounting for Management Control. Springer, Boston, MA. https://doi.org/10.1007/978-1-4899-7138-8_19

Yuniasih, N. W., N. K. Rasmini, dan M. G. Wirakusuma 2011. Pengaruh Pajak dan Tunneling Incentive Pada Keputusan Transfer Pricing Perusahaan Manufaktur Yang Listing Di Bursa Efek Indonesia. Universitas Udayana. 
First Author - Santi Yopie, santiyopie@yahoo.com

\section{AUTHORS}

Second Author - Oka Budiman

Correspondence Author - Santi Yopie, santiyopie@yahoo.com, 628117724999 